\title{
ERRATUM
}

\section{Erratum to: The Burden of Chronic Urticaria from Brazilian Patients' Perspective}

Maria-Magdalena Balp · Nilcéia Lopes da Silva $\cdot$ Jeffrey Vietri

Haijun Tian · Luis F. Ensina

Published online: August 29, 2017

(c) The Author(s) 2017. This article is an open access publication

Erratum to: Dermatol Ther (Heidelb)

DOI 10.1007/s13555-017-0191-4

In the original publication, fifth author's name was incorrectly published as Luis F. Esina. The correct name should read as 'Luis F. Ensina'.

The original article was corrected.

Open Access. This article is distributed under the terms of the Creative Commons Attribution-NonCommercial 4.0 International
License (http://creativecommons.org/licenses/ by-nc/4.0/), which permits any noncommercial use, distribution, and reproduction in any medium, provided you give appropriate credit to the original author(s) and the source, provide a link to the Creative Commons license, and indicate if changes were made.

The online version of the original article can be found under doi:10.1007/s13555-017-0191-4.

M.-M. Balp ( $\square)$

Novartis Pharma AG, Basel, Switzerland

e-mail: maria-magdalena.balp@novartis.com

N. Lopes da Silva

Novartis Biociências S.A., São Paulo, Brazil

J. Vietri

Kantar Health, Horsham, PA, USA

H. Tian

Novartis Pharmaceuticals Corporation, Global

Medical Affairs, East Hanover, NJ, USA

L. F. Ensina

Federal University of São Paulo, São Paulo, Brazil 